\title{
ROLA KATECHEZY MŁODZIEŻY W PRZYGOTOWANIU DO MAŁŻEŃSTWA
}

Na początek kilka uściśleń. Pojęcie katechezy młodzieży W Dyrektorium Ogólnym o Katechizacji odnosi się do trzech różnych grup adresatów: zakłada się tu bowiem, że wiek młodzieńczy zaczyna się okresem poprzedzającym dojrzewanie, potem odnosi się do czasu dojrzewania, a następnie do młodości (zob. DOK 181). Zwraca się przy tym uwagę, że należy odróżnić okres dojrzewania od młodości, mając świadomość, że trudno jest jednoznacznie zdefiniować ich znaczenie (tamże). Pomocne w adekwatnym podejściu do tego adresata ma być korzystanie $\mathrm{z}$ badań naukowych oraz analiza warunków życia danej społeczności. W dokumencie umieszcza się też przyjmowanie sakramentu bierzmowania w pierwszej fazie wieku młodzieńczego (poprzedzającej dojrzewanie), a więc bardzo wcześnie, to znaczy przy końcu szkoły podstawowej. W Dyrektorium katechetycznym Kościoła Katolickiego w Polsce czas bierzmowania ustalono na trzecią klasę szkoły gimnazjalnej (zob. DKP 107), choć w praktyce sakramentu bierzmowania udziela się w pierwszej klasie szkoły ponadgimnazjalnej ${ }^{1}$. Warto zapytać, czy to oddalenie w czasie ma jakiekolwiek uzasadnienie teologiczne ${ }^{2}$ ? A praktycznie rzecz biorąc, czy czekanie z bierzmowaniem tak długo - w konsekwencji pozostawiające nastolatków przechodzących przez tak istotny proces transformacji życia, jakim jest

1 Z drugiej strony polski dokument wiąże ze sobą w jednym rozdziale katechezę dzieci i katechezę młodzieży (a nie na przykład katechezę młodzieży z katechezą dorosłych, choć właściwie treść nauczania młodzieży bardziej odnosi się do przyszłości). Katecheza młodzieży nie ma też tu odrębnego miejsca, co może świadczyć o podejściu do formacji tego wieku jako jednego z wielu zadań Kościoła. Ujęcie Dyrektorium Ogólnego o Katechizacji jest w tym względzie bardziej wrażliwe na czas dorastania, nazywając osoby młode nadzieją i wyzwaniem dla Kościoła (zob. DOK 182; por. DWCH 2, ChL 46).

2 Zob. Cz. Krakowiak, Problemy teologiczne i pastoralne podczas prac nad „Ordo Confirmationis 1971”, „Seminare” 3(2014), s. 57-73; Cz. Krakowiak, Liturgia Sakramentu bierzmowania w pracach nad "Ordo Confirmationis 1971”, „Seminare” 2(2014), s. 47-59. Autor przypomina, że przez wiele wieków sakramentu bierzmowania udzielano bezpośrednio po chrzcie św. Liturgia tego sakramentu jest bezpośrednio związana z chrztem i Eucharystią, bowiem jest to sakrament wtajemniczenia chrześcijańskiego. W katechizmowej wersji listy sakramentów bierzmowanie jest na drugim miejscu, bo taki był porządek udzielania sakramentów w starożytności, II Sobór Watykański przywrócił tego świadomość (zob. KL 14, 21, 59-63, 92; DM 11, 14, 36; DA 3, 10, 12). Por. B. Wolański, Bierzmowanie $w$ duszpasterstwie, Legnica 2010, s. 34-48. 
dojrzewanie - nie ma swoich konsekwencji w odejściu ludzi młodych od Kościoła (i rezygnacji z wejścia w czas mistagogii po udzieleniu sakramentu)?

Z tym wiąże się kolejna sprawa wymagająca uściślenia, dotyczy ona sytuacji życia współczesnego młodego człowieka, a więc jego kultury. Na kulturę, ogólnie rzecz biorąc, składają się wszystkie wartości wypełniające horyzont codziennego życia człowieka, środowiska, w jakie jest zanurzony ${ }^{3}$. Jakie wartości kształtują dzisiaj człowieka młodego? To bardzo ważne pytanie, jeśli bowiem chcemy podjąć się pracy formacyjnej z nim, nawiązać z nim dialog, musimy założyć, że nas zrozumie: że znajdziemy się w przestrzeni tych wartości, które tworzą jego świat i są dla niego ważne. Chodzi zatem o jego konkretne doświadczenia, ale też świadomość braku doświadczeń, na co on może nie mieć żadnego wpływu. Nie wolno zakładać, że propozycje Kościoła spotkają się z entuzjazmem u młodzieży tylko dlatego, że ktoś uznał je za „święte”. Bez spotkania z realnym światem młodego człowieka - co więcej ze świadomością etapu rozwojowego (fazy wieku młodzieńczego) - niepodobna być wiarygodnym świadkiem orędzia zbawienia. Moc Ewangelii nie leży w jej wsobnej wartości - wszak napisali ją konkretni autorzy do konkretnych wspólnot - ale w zdolności Ewangelizatora do czynienia przyjaciół (uczniów) ${ }^{4}$. Aby można jednak było wejść w relację przyjaźni, konieczne jest zaufanie człowiekowi - a współczesny nastolatek to człowiek o diametralnie innym podejściu do życia: do przyszłości, do zawodu, do rodziny, do małżeństwa, do państwa. To człowiek „sieci”, człowiek codziennie stawiany wobec rzeczywistości wirtualnej oraz wszystkich związanych z tym zagrożeń, a zarazem szukający rozwiązań swoich problemów w utrzymaniu tempa postępu cywilizacyjnego ${ }^{5}$.

3 Zob. A. Tyszka, Kultura jest kultem wartości. Aksjologia społeczna-studia i szkice, Lublin 1993. W dokumencie II Soboru Watykańskiego czytamy: Mianem kultury w sensie ogólnym oznacza się wszystko, czym człowiek doskonali i rozwija wielorakie uzdolnienia swego ducha i ciała; stara się droga poznania i pracy poddać sam świat pod swoja władzę; czyni bardziej ludzkim życie społeczne tak $w$ rodzinie, jak $i w$ całej społeczności państwowej przez postęp obyczajów i instytucji; wreszcie $w$ dziełach swoich $w$ ciagu wieków wyraża, przekazuje i zachowuje wielkie doświadczenia duchowe i dążenia po to, aby służyły one postępowi wielu, a nawet całej ludzkości (KDK 53).

4 O wysłaniu Apostołów na misję często mówi się w technicznych formułach „nauczania” (czasem nawet „pouczania”) czy „czynienia uczniami”, co bez zrozumienia kontekstu posłania może być zrozumiane jako wezwanie do indoktrynacji bądź „nawracania”. Tymczasem pedagogia Jezusowa polegała na wejściu w relację podmiotową z grzesznikiem, przebywaniem z nim i włączaniem (wtajemniczaniem) w życie Ojca. Zawsze z zachowaniem jasno odczuwanej przez rozmówcę wolności oraz w środowisku jego życia i jego problemów (por. DOK 140).

$5 \quad$ Zob. Z. Melosik, Kultura popularna jako czynnik socjalizacji, w: Pedagogika. Podręcznik akademicki, red. Z. Kwieciński, B. Śliwerski t. 2, Warszawa 2002, s. 84-85; K. Strzyczkowski, Tożsamość w kontekście tendencji rozwojowych społeczeństwa ponowoczesnego, Warszawa 2012, s. 14-48, 134-151; T. Sobolewski, Pokolenie iPhonowych wnuków, „W drodze” 7(2014), s. 45-49. 


\section{Katecheza a nowa postać kultury}

Potoczne myślenie duszpasterskie zakłada, że przygotowanie do małżeństwa jest jednym z najpilniejszych zadań katechetycznych i pastoralnych ${ }^{6}$ W tradycyjnym ujęciu proponuje się zatem przygotowanie dalsze, bliższe i bezpośrednie do sakramentu małżeństwa (zob. FC 66). Miejscem przygotowania dalszego jest rodzina, i to w niej dziecko uczy się swojego człowieczeństwa i szacunku dla człowieczeństwa innych. Przynajmniej zakłada się - może niesłusznie, sądząc po jakości problemów wychowawczych, ilości rozwodów i różnych patologii w rodzinie - że dorośli rodzice są w stanie własnym przykładem życia małżeńskiego i rodzinnego ukazać pozytywny, wartościowy model miłości i współpracy, poszanowania życia i śmierci. Jan Paweł II mówi o "przebudzeniu religijnym” dziecka w rodzinie (zob. CT 68). Rodzice zatem przekazują wzory ról małżeńskich, kształtując obraz dojrzałej więzi międzyludzkiej, licząc na to, że ich potomstwo wyniesie z domu pragnienie zbudowania i podtrzymywania takiej więzi we własnym małżeństwie. Na tym etapie przygotowania do małżeństwa mówimy zatem o katechezie rodzinnej, którą wspomaga pozytywne ukazywanie miłości na lekcjach religii w na katechezie, we wspólnotach w parafii. Przygotowanie bliższe dotyczy pogłębienia chrześcijańskiej nauki o małżeństwie i rodzinie (i krytyczną oceną fałszywych teorii i poglądów); wprowadzenie w głębsze życie wspólnotowo-liturgiczne Kościoła i w modlitwę osobistą; oraz przysposobienie do społecznego życia we wspólnocie rodzinnej, zwłaszcza do współodpowiedzialności i współpracy z innymi, a także do współdziałania z łaską Bożą w nieustannym rozwoju osobowym (zob. DDR 24-25). Przygotowanie bezpośrednie dotyczy narzeczonych, którzy poznają teologię małżeństwa, etykę życia małżeńskiego oraz liturgię sakramentu małżeństwa.

Katecheza przygotowująca do małżeństwa wpisuje się więc z jednej strony $w$ ogólna wizje formacji młodych dorosłych, gotowych do wejścia w związek matżeński, z drugiej w program duszpasterski każdej parafii, odpowiedzialnej za pomoc dorastajacym $w$ zrozumieniu istoty małżenstwa i rodziny ${ }^{7}$. Perspektywa dalszego przygotowania każe jednak wyjść poza doraźność działania „dla narzeczonych”, i myśleć bardziej realnie o wychowaniu człowieka dojrzałego do małżeństwa i założenia rodziny poprzez katechezę młodzieży, począwszy od okresu poprzedzającego dojrzewanie, a zatem i przygotowującego do przyjęcia sakramentu bierzmowania.

6 To przekonanie wynika między innymi z wezwania do troski o rodzinę (zob. np. FC 65, gdzie Jan Paweł II pisze: Należy przeto raz jeszcze podkreślić pilna potrzebę duszpasterskiej obecności Kościoła dla podtrzymania rodziny. Trzeba podjąć każdy wysiłek, ażeby zorganizować i rozwinać duszpasterstwo rodzin, troszcząc się o tę pierwszoplanowa dziedzinę w przekonaniu, że przyszłość ewangelizacji zależy w wielkiej mierze od "Kościoła domowego"). Wyrazem tej świadomości Kościoła jest Dyrektorium Duszpasterstwa Rodzin (2003; dalej: DDR).

7 P. Poniatowski, Przygotowanie narzeczonych do małżeństwa. W poszukiwaniu nowego paradygmatu, w: Problemy dorosłych ludzi. Formacja chrześcijańska dorosłych a codzienne trudności $\dot{z} y c i a$, red. D. Kurzydło, Warszawa 2014, s. 21-27. 
Oczywiście, katecheza dzieci również jest ważna w tym przygotowaniu, ale ze względu na rodzącą się dopiero w wieku dojrzewania samoświadomość i możliwość myślenia formalnego nastolatek wydaje się dopiero odpowiednim adresatem zaproszenia do wejścia na drogę dojrzałości ludzkiej, zdolnej zbudować nierozerwalną więź z drugim człowiekiem na zasadzie świadomego i dobrowolnego przymierza miłości (przyjaźń dziecięca może być dozgonna, ale łatwo ją zranić).

Stoimy zatem na stanowisku, że ponieważ zadaniem katechezy jest prowadzenie do komunii z Jezusem Chrystusem - a zatem jej istotą jest więź (przy czym należy rozróżnić więź i związanie: istnieją bowiem więzi, ale i więzy, które mogą zniewalać miłość, wypaczać dobrowolność daru czy bezinteresowność ofiary) każda wrażliwa na więź międzyludzką, budująca przyjaźń katecheza ma znaczenie małżeńskotwórcze. Odnowa antropologiczna katechezy zakłada taką świadomość formatorów i zadanie uświadamia tego faktu młodzieży: co ogólnie można też nazwać integrowaniem wiary z ich życiem ${ }^{8}$. W tym sensie naprawdę wielką wartość posiada katecheza wtajemniczająca w jakąś relację, w tym relację z Bogiem, ale największą przeszkodą jest naiwne przeświadczenie, że zwykłe spontaniczne spotkanie automatycznie „załatwia” to zadanie. Każda katecheza powinna więc wyrastać z pragnienia zbudowania wspólnoty, komunii ${ }^{9}$ - co zakłada przede wszystkim świadomość tego, kim jest uczestnik spotkania. Być może Jezus mówiąc, by nie „rzucać pereł przed świnie” miał na myśli owo nieroztropne zaangażowanie w dialog kulturowy, w którym wychowawca ustawia siebie samego w pozycji kogoś ważniejszego, wszystkowiedzącego, posiadającego pełnię prawdy przewodnika. Tymczasem postawa taka w sytuacji katechezy młodzieży wyklucza możliwość ich zaangażowania w proces nawrócenia ze względu na naturalne prawidłowości rozwojowe tego czasu, a więc krytycyzm w postrzeganiu nauczanej rzeczywistości czy bunt wobec wartości ukazywanych jako ważne wyznaczniki życia (ten bunt ma charakter rozwojowy, to znaczy że nastolatek występując - czasem brutalnie czy wulgarnie - przeciw jakimś wartościom, próbuje w sobie właściwy sposób je sprawdzić, jakby upewnić się o trwałości, ponadczasowości, nietykalności prawdy) ${ }^{10}$. Wracamy tu do wstępnych uściśleń: na każdym etapie wieku młodzieńczego jak inna jest specyfika rozwoju osobowego, tak inne będą sposoby budowania więzi - w czasie wychodzenia $\mathrm{z}$ dzieciństwa nastolatek nie potrafi jeszcze wejść w prawdziwą relację międzyosobową, w czasie dojrzewania zaczyna robić eksperymenty dotyczące lojalności wobec grupy rówieśniczej, a pod koniec gimnazjum

8 Zob. D. Kurzydło, Kerygmatyczny i antropologiczny wymiar katechezy. Próba redefinicji katechezy, „Studia Katechetyczne” 8(2012), 82-100.

9 Roman Murawski przypomina, że od samego początku istnienia Kościoła (od dnia Pięćdziesiątnicy) katecheza przebiegała w ramach wspólnoty: przepowiadanie było owocem powołania wspólnoty i prowadziło do powstania wspólnoty (ożywienia wspólnoty). Wspólnota chrześcijańska motywowała i angażowała do dzieła ewangelizacji (nowej ewangelizacji). Zob. R. Murawski, Historia katechezy. Cz. 1 - katecheza w pierwszych wiekach, Warszawa 2011, s. 23-54.

10 Zob. J. Bagrowicz, Edukacja religijna współczesnej młodzieży. Źródła i cele, Toruń 2000, s. 90-110. 
potrafi ocenić, na czym polega wierność nie tylko teoretycznie, ale na bazie licznych eksperymentów, nieudanych prób opisać własne doświadczenie budowania relacji. Jednak do tego trzeba wziąć pod uwagę rozmaite modele relacji budowane poprzez portale społecznościowe i inne formy „życia wirtualnego” - które choć traktowane jako jedynie namiastki rzeczywistych związków, stanowią istotną część życia i spędzanego czasu nastolatka ${ }^{11}$.

\section{Kiedy zacząć przygotowanie do małżeństwa?}

W ostatnim czasie zmieniła się nie tylko kultura (i nie tylko człowiek jako twórca tej kultury czy cywilizacja jako efekt rozwoju kultury), lecz zmienił się też Kościół (jako społeczność zwołana spośród tych wszystkich ludzi oraz jego organizacja w zakresie katechezy jako wyrazu samoświadomości bycia posłanym). Kościół nie dostosowuje się więc nigdy do świata jako element globalnej ludzkiej społeczności, ale jako wspólnota żyjąca wśród tej społeczności - próbuje zrozumieć przesłanie Ewangelii w odniesieniu do współczesnych jej ludzi, żyjących nieraz całkowicie wbrew jej duchowi (choć czasem zgodnie tylko z jej literą). Stąd pilna potrzeba nowej ewangelizacji, aby nie stracić ducha Ewangelii w szybko zmieniającym się świecie ${ }^{12}$.

Wydaje się, że jednym z owoców nowej ewangelizacji może być przywrócenie katechumenalnego modelu pracy w przygotowaniu do sakramentu bierzmowania oraz w przygotowaniu do sakramentu małżeństwa. O tym pierwszym szeroko pisze Paweł Mąkosa ${ }^{13}$ - wskazując na konieczność wieloprocesowej formacji, rozciągniętej na etapy preewangelizacji, ewangelizacji i mistagogii. Katechumenat młodzieżowy lub katechumenalny model katechezy młodzieży wychodzi naprzeciw zbyt encyklopedycznemu z jednej strony, a „romantycznemu” z drugiej podejściu do pracy wychowawczej i profilaktycznej z nastolatkami. Włączenie młodzieży w drogę rozwoju wiary - który jest częścią rozwoju człowieka: ani gorszą, ani lepszą częścią, Bóg stworzył człowieka jako złożoną bytowo jednostkę - pozwala zaangażować się bardziej adekwatnie w codzienne sprawy ludzi młodych, ich doświadczenie,

11 Kenneth J. Gergen zwraca uwagę na fakt, iż wszystkie założenia na temat własnej tożsamości (kim jestem) - zwłaszcza w przypadku nastolatków, którzy znajdują się na etapie rozpoznawania własnej tożsamości - są produktami pewnej kultury w pewnym momencie jej historii (K.J. Gergen, Nasycone Ja, Warszawa 2009, s. 42). Autor dowodzi, że stale zwiększa się liczba i różnorodność związków, w które się angażujemy, rośnie potencjalna częstotliwość kontaktów, stale nasila się również ich zewnętrzna intensywność i trwałość w czasie. Ponieważ wzrost ten osiaga wartości ekstremalne, osiagamy stan społecznego nasycenia (s. 94). K.J. Gergen nazywa ten stan multifrenią.

12 Zob. Benedykt XVI, List apostolski „Ubicumque et semper” ustanawiający Papieską Radę Nowej Ewangelizacji (21 września 2010), L’OsRomPol 13 października 2010, s. 4-5; VD 96, 122.

13 Zob. P. Mąkosa, Katechezy młodzieży gimnazjalnej w Polsce. Stan aktualny i perspektywy rozwoju, Lublin 2009, s. 373-531. 
ich problemy i dążenia ${ }^{14}$. Model katechumenalny stwarza przestrzeń i możliwość doświadczeń związanych z nauczaną religią, szansę przeżycia swojej wiary we „wspólnocie inicjacyjnej”. Z kolei o katechumenacie przedmałżeńskim mówi się głównie w przypadku narzeczonych ${ }^{15}$ - wówczas ogranicza się on do krótkiego czasu „nadrobienia” pewnych zaległości, głównie katechizmowych, oraz uczestnictwa w celebracjach liturgicznych. Oczywiście, w czasach szybkiej komunikacji i ekspresowych szkoleń taki katechumenat mógłby dla narzeczonych okazać się atrakcyjną ofertą (dla wielu niczym więcej niż ofertą, nawet jeśli skonsumowaną). Tymczasem nam chodzi o podejście całościowe, to znaczy o połączenie obu katechumenatów czy modeli opartych na cechach katechumenatu, tak aby katecheza albo w początkowej fazie jakaś forma preewangelizacji oraz ewangelizacji w sensie ścisłym ${ }^{16}$ - mogła rozciągnąć się na okres całego wieku młodzieńczego, respektując różne jego fazy i potrzeby. Zatem, przygotowanie do małżeństwa - w sensie katechezy młodzieżowej, która zawsze jest ukierunkowana, jak zaznaczyliśmy, na budowanie więzi oraz podtrzymywanie więzi (a także naprawianie więzi, jeśli zajdzie taka potrzeba), przygotowując jak najbardziej prawdziwie do przyjęcia kiedyś sakramentu małżeństwa - jako decyzji wpisującej się w odpowiedzialność do podjęcia zadań człowieka dorosłego. Byłby to zarazem jeden z tych najważniejszych momentów krytycznych, kryteriów odniesienia dla osiągniecia dorosłości ${ }^{17}$.

Katechumenalny model formacji, ponieważ zasadza się na wtajemniczeniu w doświadczenie wiary, stanowi najlepszą formę wychowania człowieka. Wychodzi też naprzeciw krytyce - częściowo słusznej - tych, którzy uważają, że nauczanie chrześcijańskie stało się dla ludzi współczesnych mało zrozumiałe. Sprawy dotyczące

14 Anna Królikowska przeprowadziła szereg badań nad rozumieniem pojęć religijnych licealistów. Badania uwzględniają szeroki kontekst uwarunkowań kulturowych, filozoficznych, socjologicznych, pedagogicznych i psychologicznych, które w różny sposób współuczestniczą w kształtowaniu się świadomości religijnej. Autorka zauważyła dużą nieadekwatność (niepełność, nieprecyzyjność, błędność) sposobów rozumienia podstawowych pojęć religijnych w stosunku do Objawienia. Podstawowym problemem wydaje się brak odniesienia dla poznawanych pojęć w doświadczeniu jednostki. Zob. A. Królikowska, Pojęcia religijne młodzieży. Badania empiryczne denotacyjnego i konotacyjnego rozumienia pojęć, Kraków 2008.

15 O katechumenacie przedmałżeńskim mówiono już dawno, np. w jego sprawie I Synod Diecezji Katowickiej (1976), gdzie posiadał on raczej charakter uzupełnienia formacji religijnej dla tych, którzy nie uczęszczali na katechezę wcześniej. Zob. T. Pietrzyk, Katechumenat przedmałżeński wświetle uchwał I Synodu Diecezji Katowickiej, „Śląskie Studia Historyczno-Teologiczne” 25(1982), s. 23-29; por. J. Laskowski, Katechumenat przedmałżeński, „Chrześcijanin w świecie” 7(1976), s. 9094; P. Kulbacki, Katechumenat przedmałżeński narzeczonych, „Studia Pastoralne” 5(2009), s. 133-147.

16 Zob. W. Nowacki, Formacyjny wymiar ewangelizacji w dokumentach Magisterium Kościoła, w: Ewangelizować czy katechizować, red. S. Dziekoński, Warszawa 2002, s. 145-159.

17 Obecnie mówi się o braku punktów odniesienia dla dorosłości w sensie rzeczywistego zaangażowania się w role i zadania społeczne właściwe dla dorosłego. Zob. np. A. Lipska, W. Zagórska, Opowiadać i uczestniczyć, aby żyć - czy żyć, aby uczestniczyć, w: Psychologia narracyjna. Tożsamość, dialogowość, pogranicza red. E. Dryll, A. Cierpka, Warszawa 2011, s. 241-252. 
np. etyki małżeńskiej wymagają rzeczowej dyskusji, ponieważ - i chyba to jest najważniejsza racja zwołania przez Franciszka Synodu o rodzinie - współczesny świat nie pojmuje nauki o małżeństwie i rodzinie, o ile przedstawia się ją w tradycyjnych obrazach i pojęciach. Synod w istocie jest zatem owocem nowej ewangelizacji, o ile wypracuje odpowiedni język, którym będzie w stanie dotrzeć do serc i umysłów ludzi, zwłaszcza młodzieży. I o ile znajdzie się wystarczająco wielu świadków - temu właśnie służy katechumenat (jako wspólnota inicjacyjna: wspólnota świadków i poręczycieli, wspólnota doświadczenia obecności leczących więzi - nie więzów i wciąż uobecniającej się nadziei). Co prawda Dyrektorium Ogólnym o Katechizacji zaleca uwzględnić bardziej wymiar misyjny (prekatechumenalny), jednak mówimy tu o modelu bardziej niż zorganizowanej formie działania. Szczegółowe opracowanie programu pewnie wymaga uwzględnienia specyfiki miejsca i współpracy wielu środowisk odpowiedzialnych za pracę z młodzieżą lub przygotowanie dorosłych do małżeństwa. Najistotniejsze w tym przepracowywaniu modelu jest zawsze przekładanie na język młodego człowieka orędzia wiary - z cierpliwością i mądrością (zob. DOK 185). Franciszek zauważa, że bierność współczesnego człowieka wynika właśnie z braku doświadczenia żywej przyjaźni z Bogiem (zob. EG 81-83) ${ }^{18}$.

\section{Katecheza uobecniająca więzi przyjaźni}

Dorastający człowiek, znajdując się pomiędzy dzieciństwem a dorosłością, siłą rzeczy przeżywa czas chaosu i zamętu, czas prawdziwej walki o siebie. Dawniej czas ten wypleniało poznawanie mitów, które poprzez rytuały przejścia uzdalniały go do wyruszenia w „podróż bohatera” i „ponownych narodzin” ${ }^{19}$. Adolescent miał okazję w ten sposób nie tylko lepiej poznać siebie i zmagać się pod okiem starszyzny ze swoim lękiem i bezsilnością, ale także poznać, skąd pochodzi, jakie są jego korzenie i co stanowi o jego wartości. Był to czas przekroczenia pewnej oznaczonej granicy: granicę tę stanowiło uznanie, przez już wtajemniczonych, zdolności do podjęcia życia dorosłego człowieka, zdolnego podjąć opiekę nad innymi. Tę granicę stanowiła śmierć ego, śmierć własnych rojeń o władzy nad światem, o własnej niezależności i niezniszczalności ${ }^{20}$. Jednak nie stawało się to za pomocą jakieś aktu, który miałby stanowić dowód czy potwierdzenie zdatności,

18 Zob. J. Bagrowicz, Towarzyszyć wzrastaniu, Toruń 2006, s. 82-90; B. Wolański, Bierzmowanie w duszpasterstwie, dz. cyt., s. 222-230.

19 Zob. J. Campbell, Bohater o tysiącu twarzy, Warszawa 2013; M. Eliade, Aspekty mitu, Warszawa 1998.

20 Zob. R. Rohr, Tożsamość mężczyzny. Pięć kroków męskiej inicjacji, Kraków 2008, s. 43-123. 
siłą pewności stanowiła gwarancja wspólnoty, która okazywała radość z faktu, że mogą liczyć na przyjaźń nowego „bohatera”21.

Jeśli struktura osobowa człowieka przejawia się w czynie i poprzez czyn urzeczywistnia $^{22}$, żeby możliwe było wychowanie i przygotowanie do małżeństwa, niezbędne jest dać młodemu człowiekowi przestrzeń do praktykowania przyjaźni. Być może nieumiejętność wchodzenia w relacje i budowania wiernych związków, i troszczenia się o swoje małżeństwo jest konsekwencją niewiedzy, nieumiejętności, braku przykładów oraz podejmowania samodzielnych prób w wieku młodzieńczym, począwszy od pierwszej jego fazy. Ludzie na pewno chcą trwałego związku wszak obiecują to sobie jeszcze przed ślubem: „będę z tobą na zawsze”. Jeśli im to nie wychodzi, to stoimy wobec bardzo poważnej decyzji naprawienia tego błędu i aktywowania mnóstwa przestrzeni, w której można by uczyć się prawdziwej przyjaźni. Jezus potępiał składanie ofiar kultycznych z sercem wyzutym z przyjaźni. Jego pedagogia (na której opieramy też kult, liturgię) opierała się na wchodzeniu w relacje prawdziwej przyjaźni. A ponieważ przyjaźń domaga się wierności - a tę można też tylko deklarować, a potem nie podołać jej wyzwaniom - konieczna jest jakaś forma „wypróbowania się”. To wypróbowywanie się jest charakterystyczne dla czasu młodości ${ }^{23}$. Dlatego próba, przed jaką można postawić dorastającego człowieka - próba powiązana ze śmiercią ego - wygląda na cudowny lek, jakiego potrzebuje współczesny nastolatek. Pozostaje tylko do znalezienia odpowiednia forma realizacji tego zadania. A ponieważ $\mathrm{w}$ istocie przypomina to starożytne rytuały przejścia, i ponieważ łatwo byłoby połączyć je z jakimś katechumenalnym modelem pracy formacyjnej, warto pomyśleć o stworzeniu takiego modelu, który odpowiadałby również potrzebom młodzieży, nadto wychodził naprzeciw przygotowaniu do małżeństwa poprzez stwarzanie przestrzeni dla doświadczenia prawdziwej przyjaźni (międzypokoleniowej także). Katecheza, powiązana z procesem stałego nawrócenia, stałaby na straży wtajemniczenia oraz przekazywania pewnej wiedzy - podobnie jak w społecznościach pierwotnych starszyzna instruowała adeptów o jego przodkach, wprowadzając go w mity plemienia i opowieści o początku dziejów. W takim katechumenalno-rytualnym otoczeniu, z pewnością młody człowiek mógłby odnaleźć alternatywną dla światowych wersję ponow-

\footnotetext{
${ }^{21}$ Wobec braku rytuałów przejścia w dorosłość młodzież sama organizuje sobie zastępcze formy dorastania: poprzez zachowania aspołeczne, niebezpieczne, ryzykowne, przestępcze itp., wprowadza siebie w stan „superbohatera”, który próbuje ukraść moc bogom, pokonując strażników strzegących do nich dostępu (tabu). Mając możliwość dostępu do świata wykreowanego nie tylko w wizjach narkotycznych, ale poprzez gry komputerowe oraz fabularne, zwiększa poziom emocji i z łatwością emigruje z trudnej rzeczywistości codziennej egzystencji. Zob. W. Zagórska, Uczestnictwo młodych dorostych w rzeczywistości wykreowanej kulturowo. Doświadczenie, funkcje psychologiczne, Warszawa 2004.

22 Zob. E. Cyrańska, Duchowa rzeczywistość czyniąca człowieka osobą (koncepcja K. Wojtyły), „Paedagogia Christiana” 2(2002), s. 82.

${ }^{23}$ Zob. E.H. Erikson, Dopełniony cykl życia, Poznań 2002, s. 73-74, 90-95.
} 
nych narodzin i przeżycia „podróży bohatera”. Świadomy obecności przyjaciół, którzy go nie porzucą - bo sami przeszli i teraz razem z nim przechodzą drogę wtajemniczenia ${ }^{24}$.

Droga przejścia - przejścia $\mathrm{z}$ dzieciństwa $\mathrm{w}$ dorosłość, z pragnienia miłości do praktykowania wiernej miłości - wiedzie przez budowanie relacji przyjaźni z człowiekiem. Przywołane tu „rytuały przejścia” i zaczerpnięte z antropologii i etnologii obrazy dorastania stanowią jedynie argument za zasadnością podążania w stronę budowy modelu uwzględniającego zakorzenienie w przeszłości (tożsamość odkrywana także w relacjach z przodkami) oraz tęsknotę współczesnego nastolatka za doświadczeniem sacrum ${ }^{25}$. Katecheza młodzieży wymaga dostarczania mu takich możliwości, i ciągłego potwierdzania przynależności - nastolatek bez przynależności do kogoś traci pewność siebie, izoluje się, staje się agresywny ${ }^{26}$. Przyjaźń jest dla niego prawdziwym kołem ratunkowym. A rozwojowo przygotowuje go podjęcia się życiowego (dorosłego) zadania zbudowania opartej na przyjaźni relacji wiernej (oblubieńczej) miłości ${ }^{27}$.

Ponieważ w naturalny sposób w wieku młodzieńczym (w każdej fazie) człowiek dąży do wejścia w związki z ludźmi (rówieśnikami), należy katechezę w tym długim okresie czasu koncentrować na doświadczeniach związanych z rozwijaniem przyjaźni. Ten czas to preludium do najważniejszej decyzji, jaką będzie wybór jednego człowieka, z którym pozostanie się przez resztę życia jako mąż i żona ${ }^{28}$. Ponieważ w kulturze - między innymi za sprawą mediów - dominuje romantyczny obraz związku małżeńskiego, ograniczający miłość do zakochania i miłego spędzania czasu ze sobą, katecheza winna stanowić, na przekór młodzieńczemu idealizmowi który musi ulec zranieniu (rytualna rana ${ }^{29}$ ) - urealniające doświadczenie prawdziwej

${ }^{24}$ Zob. T. Gadacz, Wychowanie jako spotkanie osób, w: Wychowanie personalistyczne, red. F. Adamski, Kraków 2005, s. 213-221.

${ }^{25}$ Por. R. Szauer, Wpływ stylu życia na religijność młodzieży. Analiza socjologiczna, w: Religia i Kościół w świadomości katolików świeckich w Polsce i w Niemczech. Kontynuacja czy zmiana nastawienia?, red. J. Baniak, Poznań 2013, s. 89-106.

26 Zob. J. Mastalski, Samotność globalnego nastolatka, Kraków 2007.

${ }^{27} \mathrm{~W}$ tym sensie katechumenat przedmałżeński oznaczałby przejście od zestawu tematów katechizmowych, najczęściej przypominajacych podstawowe zagadnienia wiary i moralności, w kierunku wydarzenia ewangelizacyjnego, którego owocem jest budzenie wiary lub pogłębianie jej i konsekwentne budowanie postaw moralnych pod kątem późniejszego życia matżeńskiego (Piotr Kulbacki, Katechumenat przedmatżeński narzeczonych, art. cyt., s. 141).

28 Por. J. Grzybowski, Jak przygotować do małżeństwa?, „Przegląd Powszechny” 9(2012), s. 41-51. Franciszek Blachnicki przypomina, że łatwo zagubić personalistyczny wymiar sakramentów, jeśli katecheza ogranicza się do podawania wiedzy o zasadach moralnych, zaś udzielanie sakramentów staje się "narzędziem” do realizacji postulatów moralnych, związanych z życiem małżeńskim czy rodzinnym. Zob. F. Blachnicki, Kościół jako wspólnota, Lublin 1992, s. 151.

29 Steve Biddulph uważa, że częścią inicjacji w dorosłość było rytualne doświadczenie zranienia: rana miała przypominać, że życie dorosłego jest pełne niebezpieczeństwa, na które wystawia niepotrzebne ryzyko. Ponieważ młodzi ludzie łatwo podejmują zachowania ryzykowne, chcąc udowodnić, 
przyjaźni, dzięki czemu budowanie miłości małżeńskiej stanowi wyzwanie na życie. Poznanie Jezusa Chrystusa i pełna komunia z Nim nie oznacza zmuszania do ukochania historycznej postaci, ale do zaangażowania się w uobecnioną w przyjaźni między ludźmi autentyczną miłość. Dlatego kluczem do odczytania idei „katechumenatu przedmałżeńskiego” jest pojęcie „Kościoła domowego” (zob. np. KK 11, DA 11, FC 51).

Pamiętając, że małżeństwo jest dynamiczna wspólnota kobiety i mężczyzny, w której - dzięki współdziałaniu - rozwija się i pogłębia miłość, a wspólne realizowanie wytyczonych celów $i$ afirmowanie określonych wartości prowadzi do wypetniania zadań małżeńskich i rodzicielskich ${ }^{30}$, konieczne jest stopniowe i długoplanowe (katechumenalne) prowadzenie do małżeństwa. To droga „bohatera”, który przekonuje się, że do udanego życia najbardziej potrzebni są ludzie, z którymi można wejść w dojrzałe relacje. To one ocalają człowieka przed izolacją, wykluczeniem, gwarantują lepsze zdrowie i spełnienie osobiste. $\mathrm{W}$ czasach, kiedy sam katechumenat rodzinny nie wystarcza, by przygotować młodzież do małżeństwa, brak katechezy poważnie zaangażowanej w to przygotowanie już od początku czasu młodzieńczego może poważnie zagrażać zdolnościom młodych ludzi do poradzenia sobie z podjęciem świadomej decyzji o sakramencie małżeństwa, a potem umiejętnościom współpracy z łaską sakramentalną ${ }^{31}$.

że mają boska moc, upokorzenie chłopca i śmierć ego miały wzbudzić w nim szacunek do życia i innych ludzi. Zob. S. Biddulph, Męskość, Poznań 2005, s. 146-155.

30 M. Ryś, Psychologia malżeństwa warysie, Warszawa 1999, s. 5.

31 Por. C. Sękalski, Tracona szansa czy zapowiedź wiosny? Przygotowanie do małżeństwa w Kościele, „Przegląd Powszechny” 9(2012), s. 52-60. Gdy ta świadomość towarzyszy formacji nastolatków, można mówić też w pewnym sensie o katechezie integralnej, której postulaty wysuwał Mieczysław Majewski (zob. M. Majewski, Tożsamość katechezy integralnej, Kraków 1995). Katecheza integralna jest w stanie dostarczyć języka zdarzeń, sama staje się zdarzeniem, doświadczaniem rzeczywistości całą osobą, nie tyle skupia się argumentacji wagi Objawienia, co jest świadectwem jego żywotności w świecie (zob. s. 134; por. DOK 152). 